\title{
Annotatie
}

\section{Wat is een nadeel voor de mededinging en wie bepaalt dat? Over de rol van deskundigen en de bewijsstandaard in het kader van discriminatie door een dominant platform}

\author{
Rechtbank Amsterdam 21 maart 2018, ECLI:NL:RBAMS:2018:1654
}

Jotte Mulder*

\section{Inleiding}

In deze zaak, die ziet op een geschil tussen Funda B.V. (Funda) en VBO Makelaar (VBO), staat de vraag centraal wanneer sprake is van misbruik van een economische machtspositie in de context van een schadetheorie die is gebaseerd op discriminatie van afnemers door een dominante onderneming. VBO-makelaars hebben weliswaar toegang tot de populaire website van Funda (funda. nl) maar worden niet op dezelfde manier gepresenteerd in de zoekresultaten op de website en hebben geen toegang tot een aantal functionaliteiten van de website waar NVM-makelaars wel toegang tot krijgen. VBO stelt zich op het standpunt dat dit een nadeel oplevert voor de concurrentiepositie van de bij haar aangesloten makelaars en gezien moet worden als misbruik van een economische machtspositie (emp). De rechtbank oordeelt dat sprake is van een emp maar dat geen sprake is van mis-

Mr. dr. J. Mulder is werkzaam bij de ACM en tevens universitair docent aan de Universiteit van Utrecht. Deze annotatie is geschreven op persoonlijke titel. Met dank aan Wolf Sauter voor zeer nuttig commentaar op een eerdere versie. bruik. De uitspraak van de Rechtbank Amsterdam is reeds besprekingswaardig vanwege het feit dat zowel het bestaan van de machtpositie als het gestelde misbruik voorzien wordt van een volledige beoordeling. Vaak worden civiele zaken afgedaan op basis van het feit dat onvoldoende is gesteld voor de vaststelling van een emp of wordt er direct beoordeeld dat geen sprake is van een misbruiksituatie (als dat evident is). De vaststelling van de emp is des te opvallender gezien het feit dat het hier gaat om een tweezijdige platformmarkt waar netwerkeffecten een belangrijke rol lijken te spelen. De vaststelling van dominantie op een dergelijke markt vereist daarom een complexe economische analyse. Daarnaast is de uitspraak relevant om met name twee redenen. In de eerste plaats vanwege de wijze waarop de rechtbank tot die vaststelling komt, namelijk op basis van het gebruik van een deskundigenrapport hetgeen in de Nederlandse rechtspraktijk (nog) niet zo gebruikelijk is. In de tweede plaats vanwege de centraal staande schadetheorie in deze zaak die atypisch is en aanleiding geeft tot enige reflectie op de verhouding tussen zogenoemde uitsluiting- en exploitatie/discriminatoire vormen van misbruik en de verschillende bewijsstandaarden die daarvoor gelden. Deze reflecties komen terug in onderdeel vier van de annotatie. Hieronder zal ik eerst de feiten van de zaak bespreken en vervolgens de uitspraak van de rechtbank. 


\section{Feiten}

De Nederlandse Vereniging voor Makelaars (NVM) heeft de succesvolle website funda.nl opgezet. Op funda.nl worden onder meer woningadvertenties van bij NVM, VBO en VastGoedPRO aangesloten Nederlandse makelaars aan bezoekers getoond, waarbij geen vergoeding aan bezoekers van de website in rekening wordt gebracht. In 2008 zijn NVM en funda een samenwerkingsovereenkomst aangegaan met VBO en VastgoedPro op basis waarvan laatstgenoemden de mogelijkheid zouden krijgen om hun woningaanbod tevens op funda.nl te plaatsen. Reeds ten tijde van het overeenkomen van deze samenwerking hebben partijen afgesproken 'dat het aandeelhouderschap van NVM in Funda en de omvang van het NVM-aanbod met zich meebrengen dat het NVM-aanbod een bijzondere positie inneemt ten opzichte van het overige aanbod op Funda (...). ${ }^{11}$ Dit is vervolgens de kern van het geschil geworden tussen Funda/NVM en VBO.

Deze bijzondere positie houdt namelijk in dat voor wat betreft de plaatsing op de website (1) NVM-leden een lagere vergoeding betalen ( 25 euro voor NVM- versus 160 euro voor VBO-leden); (2) in de presentatie van zoekresultaten het VBO-aanbod volgt na al het NVMaanbod (ongeacht de relevantie van de zoekresultaten); (3) de VBO-makelaars geen toegang hebben tot alle functies van de website. Ten slotte hebben VBO-makelaars ook geen toegang tot de zogenoemde objectinformatiedatabase. NVM is rechthebbende op een databank met historische gegevens en een databank met actuele gegevens over in Nederland gelegen onroerende zaken die (ooit) via NVM-leden te koop zijn aangeboden (de objectinformatiedatabase). Die wordt onder meer gebruikt bij taxaties.

VBO stelt zich op het standpunt dat Funda hiermee artikel 24 van de Mededingingswet (Mw) en artikel 102 van het Verdrag betreffende de werking van de Europese Unie (VWEU) overtreedt. De discriminatore behandeling van VBO-makelaars zou kwalificeren als misbruik van een economische machtspositie. Aldus verlangt VBO toegang tot funda.nl op non-discriminatoire wijze en een schadevergoeding.

De zaak loopt al enige jaren. In 2015 heeft de rechtbank zich eerst in een tussenvonnis uitgelaten over enkele procedurele kwesties en vastgesteld dat het nodig is om ten aanzien van de vaststelling van de relevante productmarkt de mogelijke emp van Funda en de gewraakte handelspraktijken inlichtingen in te winnen bij deskundigen. $^{2}$

\section{Het deskundigenbericht}

De uitspraak van de rechtbank geeft alleen een samenvatting van het deskundigenbericht en bevat helaas wei- nig details. ${ }^{3}$ De relevante markt wordt afgebakend als de markt voor huizensites in Nederland. Funda is volgens de deskundigen in het bezit van een machtspositie op deze markt vanwege het feit dat funda.nl een bijzonder sterke positie inneemt ten opzichte van andere huizensites en er significante toetredingsbarrières bestaan in de markt voor huizensites in Nederland. Individuele verkoopmakelaars kunnen niet om funda.nl heen. Voor het vaststellen van de productmarkt hebben de deskundigen diverse (online en offline) advertentiekanalen voor het aanbod van particuliere koopwoningen onderzocht en geanalyseerd in hoeverre die op grond van hun kenmerken, prijzen en het gebruik daarvan door zowel huizenkopers als verkoopmakelaars onderling substitueerbaar zijn. Ze hebben het door hen gekozen economisch raamwerk voor marktafbakening - ook aan de hand van de door partijen ingebrachte standpunten en deskundigenrapporten - toegelicht. Daarbij is ook betrokken dat in de onderhavige zaak meerdere markten relevant kunnen zijn, en de relevantie daarvan hebben deskundigen in hun afwegingen betrokken. Ten aanzien van het misbruik merken de deskundigen op dat daarvoor 'meer economische en juridische factoren relevant [zijn] dan de deskundigen in het deskundigenbericht hebben besproken'. ${ }^{4}$ De deskundigen stellen echter dat op basis van hun effectenanalyse geen bewijs is gevonden dat sprake is van een merkbaar effect op de concurrentiepositie van NVM-makelaars ten opzichte van niet-NVMmakelaars.

\section{De uitspraak}

De rechtbank neemt het deskundigenrapport ten aanzien van de emp over. De centrale kwestie in de uitspraak ziet vervolgens op de vraag of Funda misbruik heeft gemaakt van haar machtspositie. ${ }^{5}$ De rechtbank overweegt eerst dat het toepassen van ongelijke voorwaarden ten opzichte van handelspartners voor gelijkwaardige prestaties op zichzelf niet verboden is. Er is pas sprake van misbruik van een machtspositie wanneer dergelijk gedrag de mededinging vervalst of de concurrentiepositie van de handelspartners aantast. Wanneer is daar sprake van? In de eerste plaats moet dat nadeel volgens de rechtbank verder strekken dan 'het gewone "nadeel" dat uit de discriminatie zelf voortvloeit voor de ongelijk behandelde handelspartners'. De rechtbank acht het tevens relevant dat het door VBO c.s. gestelde nadeel bij de mededinging zich niet voordoet op de door de deskundigen afgebakende markt zelf, namelijk de markt voor huizensites in Nederland, maar op de stroomafwaartse markt voor woningmakelaardij. ${ }^{6}$

3. Rb. Amsterdam 21 maart 2018, ECLI:NL:RBAMS:2018:1654, vanaf r.o. 2.4 .

4. Rb. Amsterdam 21 maart 2018, ECLI:NL:RBAMS:2018:1654, r.o. 2.6.3.

5. Rb. Amsterdam 21 maart 2018, ECLI:NL:RBAMS:2018:1654, r.o. 2.8 e.v.

6. Rb. Amsterdam 21 maart 2018, ECLI:NL:RBAMS:2018:1654, r.o. 2.9 
De volgende criteria worden door de rechtbank als doorslaggevend geacht (met verwijzing naar British Airmays, ECLI:EU:C:2007:166 en Post Danmark II, ECLI:EU:C:2015:651): (1) het onderzoek naar vermeend misbruik moet plaatsvinden met het in aanmerking nemen van alle omstandigheden van het concrete geval; (2) uit dat onderzoek moet volgen dat het gedrag niet alleen discriminerend is, maar ook tot doel of de neiging heeft de concurrentieverhouding scheef te trekken (afbreuk te doen aan de mededingingspositie van een deel van de handelspartners van deze onderneming jegens anderen); (3) het mededingingsverstorende effect mag niet louter hypothetisch zijn maar er hoeft niet te worden bewezen dat het gedrag van de onderneming met een machtspositie een kwantificeerbare daadwerkelijke verslechtering van de mededingingspositie van één of meer handelspartners heeft meegebracht of merkbaar is. $^{7}$

De rechtbank sluit in aanvulling hierop aan bij een recente opinie van advocaat-generaal Wahl in de $M E O$ zaak (C-525/16). De rechtbank stelt dat moet worden onderzocht of de discriminatie het vermogen van de benadeelde handelspartners om een effectieve concurrentiedruk op de bevoordeelde handelspartners uit te oefenen kan aantasten [cursivering JM]. Het bestaan van een nadeel bij de mededinging zou moeten worden vastgesteld door de daadwerkelijke of potentiële gevolgen van de discriminatie te onderzoeken in het licht van alle relevante omstandigheden die verband houden met de betrokken transacties, alsook met de kenmerken van de markt maarop de handelspartners van de onderneming met een machtspositie merkzaam zijn [cursivering JM] ${ }^{8}$ In dat onderzoek moet volgens de rechtbank in de eerste plaats aandacht uitgaan naar de realiteit en het relatieve belang van de discriminatie en vervolgens moet ook belang worden gehecht aan het onderzoek van de omvang van de kosten van de door de dominante onderneming geleverde producten/diensten tegenover de totale door de benadeelde handelspartner gedragen kosten.

Ook voor dit deel van de beoordeling sluit de rechtbank grotendeels aan bij de beoordeling van de deskundigen. ${ }^{9}$ De deskundigen hebben bekeken of het VBO-woningaanbod op de website minder gezien wordt dan het NVM-aanbod, of de ontwikkelingen in de marktaandelen van makelaars relevante informatie opleverde, en geanalyseerd of NVM-huizen meer en/of sneller verkocht worden dan VBO-huizen. De conclusies waren dat huizen van NVM-makelaars gemiddeld vaker bekeken worden dan huizen van niet-NVM-makelaars en dat dit tot een verschil leidt in het gemiddeld aantal contactaanvragen: een VBO- of VastgoedPRO-object heeft gemiddeld 16 procent minder contactaanvragen dan een NVM-object. Op grond van cijfermatig onderzoek concluderen de deskundigen echter dat geen aanleiding bestaat om te concluderen dat de achterstelling op fun-

7. Rb. Amsterdam 21 maart 2018, ECLI:NL:RBAMS:2018:1654, r.o. 2.10-2.11.

8. Rb. Amsterdam 21 maart 2018, ECLI:NL:RBAMS:2018:1654, r.o. 2.12.

9. Rb. Amsterdam 21 maart 2018, ECLI:NL:RBAMS:2018:1654, r.o. 2.17 e.v. da.nl een negatief effect heeft gehad op niet-NVMmakelaars zoals VBO omdat de marktaandelen sinds 2009 niet zijn afgenomen en ze het in Zeeland goed doen. Daarnaast stellen de deskundigen vast dat NVMmakelaars beter presteren (met name op basis van snelheid van verkoop) dan die van VBO en VastgoedPRO op landelijk niveau. Maar er zijn ook provincies, en bepaalde tijdsperiodes, waar VBO-makelaars juist beter presteerden. Al met al concluderen zij dat de effectenanalyse geen eenduidige aanwijzingen oplevert dat de achtergestelde plaatsing op funda.nl een effect heeft gehad op de concurrentiepositie [cursivering JM] van NVM-makelaars ten opzichte van niet-NVM-makelaars. Met betrekking tot het ontbreken van toegang tot de informatiedatabase stelt de rechtbank vast dat de stellingen van VBO c.s. omtrent het door haar daardoor geleden nadeel, slechts zien op een nadeel voor haar als onderneming. Zij stelt geen feiten of omstandigheden op grond waarvan zou kunnen worden geoordeeld dat deze nadelen ook een nadelig effect zouden kunnen hebben op haar concurrentiepositie.

\section{Commentaar}

Zoals aangestipt in de introductie valt deze uitspraak vooral op vanwege de vaststelling van een emp op een platformgedomineerde markt, het gebruik van het deskundigenrapport en de invulling van een schadetheorie gebaseerd op discriminatoir gedrag.

\section{De dominantie van funda.nl op een} platformmarkt

De emp wordt door de rechtbank aangenomen op basis van het deskundigenrapport. Er worden geen details genoemd in de uitspraak met betrekking tot de marktaandelen van funda.nl maar het is blijkbaar evident dat funda.nl de voornaamste speler is op de vastgestelde markt voor huizensites in Nederland. In een gepubliceerd rapport van SEO (weliswaar uitgevoerd in opdracht van VBO) uit 2012 wordt inderdaad een marktaandeel genoemd van rond de 60 procent. ${ }^{10}$ Nummer 2 in de markt is Jaap.nl met een marktaandeel van rond de 9-10 procent. Jaap.nl positioneerde zich in 2007 als een maverick in de markt en integreerde tevens het huizenaanbod van onder meer funda.nl op de eigen website. ${ }^{11}$ Samen met wat andere vernieuwende functionaliteiten wist Jaap.nl daarmee in 2007 in een zeer korte periode zo'n 9 procent marktaandeel te winnen. In reactie daarop heeft Funda toen de website opengesteld voor niet-NVM-makelaars. Omdat het aanbod van Funda daarmee weer een stuk groter werd, lukte het klaarblijkelijk om de opmars van Jaap.nl een halt toe te roepen. Het is interessant en enigszins paradoxaal dat het toegankelijk maken van de website door Funda voor niet-

10. Zie www.seo.nl/uploads/media/2012-08_Ongezien_onverkocht.pdf (laatst geraadpleegd op 22 juni 2018).

11. Onderwerp van een procedure in o.m. Rb. Alkmaar 24 januari 2008 , ECLI:NL:RBALK:2008:BC2614. 
NVM-makelaars een oorsprong vindt in een poging de opmars van Jaap.nl in de markt een halt toe te roepen. Het voorbeeld van Jaap.nl lijkt een aanwijzing dat de relevante markt in kwestie dynamisch is en dat innovatieve nieuwe spelers kansen hebben om de marktpositie van funda.nl in korte tijd aan te vallen. De rechtbank identificeert echter op basis van het deskundigenrapport significante toetredingsbarrières. Dit wordt niet verder gespecificeerd maar zal te maken hebben met netwerkeffecten die doorgaans een grote rol spelen in het kader van platformmarkten. Kopers en verkopers worden via funda.nl aan elkaar gekoppeld (de welbekende tweezijdige markt), waarbij de waarde van de site toeneemt als een groter deel van verkopers de woning op de site zet en als een groter deel van de kopers de site gebruikt (het welbekende netwerkeffect). ${ }^{12}$ Funda fungeert daarmee voor een significant deel van de huizenzoekers als toegangspoort naar het woningaanbod in Nederland. Daarbij zal ook de marktnaam van funda.nl kunnen fungeren als een toetredingsbarrière. Bevestiging van de dominantie van Funda kan voorts nog gevonden worden in het feit dat er tussen de kleinere spelers in de markt wel sprake is van wat beweging en concurrentie maar het marktaandeel van funda.nl sinds de openstelling van de website niet significant lijkt te zijn veranderd. ${ }^{13}$

\section{De rol van het deskundigenbericht}

Het gebruik van een deskundigenbericht om tot een vaststelling te komen van een emp is niet geheel nieuw ${ }^{14}$ maar dat het deskundigenbericht zo een prominente rol speelt in de uitspraak is wel opvallend. In zijn algemeenheid geldt ten aanzien van de waardering van een deskundigenbericht de algemene regel van artikel 152 lid 2 Rv: 'De waardering van het bewijs is aan het oordeel van de rechter overgelaten, tenzij de wet anders bepaalt.' De vrijheid van de rechter vloeit voort uit het gegeven dat de rechter vrij is zich al dan niet te doen voorlichten door een deskundige (art. 194 lid $1 \mathrm{Rv}$ ). De verwachting hierbij is dat als de rechter eenmaal besloten heeft dat hij deskundige voorlichting nodig heeft en hij vervolgens één of meer deskundigen heeft gekozen en benoemd, het ook voor de hand ligt dat de rechter de visie van die deskundige(n) doorgaans zal volgen. ${ }^{15}$ Ingeval de opinie van andere deskundigen op gespannen voet staat met die van de door de rechter benoemde des-

12. Zie verder ook D. Mandrescu, 'Applying EU competition law to online platforms: the road ahead - Part 1', European Competition Law Review 2017, nr. 8, p. 353-365; D. Mandrescu, 'Applying EU competition law to online platforms: the road ahead - Part 2', European Competition Law Review 2017, nr. 9, p. 410-422.

13. www.seo.nl/uploads/media/2012-08_Ongezien_onverkocht.pdf.

14. Bijvoorbeeld in HR 25 oktober 2013, ECLI:NL:PHR:2013:1108.

15. Uit de Parlementaire Geschiedenis nieuw bewijsrecht (Deventer: Wolters Kluwer 1988, p. 331) volgt: 'De betrouwbaarheid van de door de rechter benoemde deskundige is mede gelegen in de omstandigheid dat hij niet door een partij is uitgekozen, maar - na overleg met beide partijen - werd aangezocht en benoemd door de rechter.' Het is uiteraard niet de bedoeling dat de beslechting van het geschil tussen partijen aan de deskundige wordt overgelaten; het is de taak van de rechter het deskundigenadvies te wegen, mede in verband met eventueel ander bewijsmateriaal. Uiteindelijk moet de rechter uiteraard ook de vertaalslag maken naar de juridische kwalificatie van hetgeen in een deskundigenbericht is vastgesteld. kundige maar de rechter de zienswijze van de aangestelde deskundige volgt, dan hoeft zijn beslissing in het algemeen niet verder te worden gemotiveerd dan dat de rechter aangeeft dat de motivering van de aangewezen deskundige hem overtuigend voorkomt. ${ }^{16} \mathrm{Wel}$ zal de rechter op specifieke bezwaren van partijen tegen de zienswijze van de door hem aangewezen deskundige moeten ingaan, als deze bezwaren een voldoende gemotiveerde betwisting inhouden van de juistheid van deze zienswijze. ${ }^{17}$ Ten aanzien van de vaststelling van een emp door de deskundigen voert funda.nl een aantal bezwaren aan. Waar die precies op zien, blijft onduidelijk. De rechtbank wijst de bezwaren af door middel van de vaststelling dat de deskundigen grondig hebben gereageerd op deze bezwaren van Funda en dat het rapport voldoet aan de daaraan te stellen eisen van onpartijdigheid, consistentie, inzichtelijkheid en logica. Daarmee is onder deze omstandigheden bij het gebruik van een deskundigenbericht in feite sprake van een minirechtbank in de rechtbank waarbij de deskundigen fungeren als beslissers en de rechters uiteindelijk slechts nog marginaal toetsen of sprake is van een quasi 'kennelijke beoordelingsfout'. Dit roept uiteraard tal van vragen op met betrekking tot procedurele waarborgen, de rol van economisch bewijs en de deskundigheid van rechters maar die strekken voorbij deze annotatie waarbij ik voor het overige toch ook vooral wil stilstaan bij de inhoud. ${ }^{18}$ Voor de transparantie in de rechtspraktijk en gezien het feit dat het niet uitgesloten is dat de vastgestelde emp van funda.nl in de toekomst in meer procedures relevant is, zou het voor de rechtsontwikkeling nuttig zijn geweest als een vertrouwelijke versie van het deskundigenrapport werd gepubliceerd, in het bijzonder omdat de rechtbank voor alle beslissende en materiële punten in de uitspraak naar het deskundigenrapport verwijst.

Het misbruik: wat is de relevante schadetheorie voor discriminatie?

Ook bij de invulling van de vraag of sprake is van misbruik van een emp speelt het deskundigenrapport een cruciale rol in de uitspraak. Op dit punt wordt de uitspraak echter tevens een stuk contentieuzer. Het gestelde misbruik ziet op een situatie waar ten opzichte van handelspartners ongelijke voorwaarden worden gehanteerd bij ongelijke prestaties, hun daarmee nadeel berokkenend bij de mededinging. De centrale vraag is hoe dat nadeel dan moet worden gespecificeerd. De recente $M E O$-uitspraak van het Hof van Justitie zag specifiek op deze vraag en in de uitspraak zoekt de rechtbank aan-

16. Zie HR 5 december 2003, ECLI:NL:HR:2003:AN8478 (Nieuw Vredenburgh/NHL).

17. HR 5 december 2003, ECLI:NL:HR:2003:AN8478 (Nieuw Vredenburgh/ $N H L)$.

18. Zie voor een mooie reflectie hierop 'Middle Temple Guest Lecture Expert Evidence: use, abuse and boundaries', Lord Hodge, Justice of The Supreme Court, 9 oktober 2017, toegankelijk op www. innertemplelibrary.com/2017/10/expert-evidence-use-abuse-andboundaries-lord-hodge-supreme-court/ (laatst geraadpleegd op 25 juni 2018). 
sluiting bij de conclusie van advocaat-generaal Wahl die op dat moment net gepubliceerd was. ${ }^{19}$

In het verbod op discriminatie zit een zekere mate van ambiguiteit omdat het economisch efficiënt kan zijn en wenselijk om tussen afnemers te differentiëren, of de mededinging te stimuleren tussen verschillende afnemers via het hanteren van verschillende prijzen voor afnemers (afhankelijk bijvoorbeeld van de verkoopinspanningen van een retailer). ${ }^{20}$ Vandaar dat advocaatgeneraal Wahl in zijn conclusie in $M E O$ stelt dat sprake moet zijn van een significant concurrentienadeel voor de afnemers in kwestie. In zijn conclusie stelt Wahl daarbij dat het belangrijk is in deze analyse een onderscheid te maken tussen verticaal geintegreerde en niet-geintegreerde ondernemingen. De verticaal geïntegreerde onderneming heeft namelijk een duidelijk belang bij potentiële discriminatie omdat een dochteronderneming in directe concurrentie kan staan met een afnemer. De niet-verticaal geintegreerde onderneming heeft echter in principe alleen maar belang bij een concurrerende afnemersmarkt. Vandaar dat de inhoudelijke analyse van de schadetheorie daar rekening mee zou moeten houden.

Advocaat-generaal Wahl suggereert zelfs dat prijsdiscriminatie van een verticaal geïntegreerde onderneming gelijkgesteld moet worden met een vorm van eerstelijnsdiscriminatie die is gericht op het uitsluiten of verzwakken van de concurrentie (zoals roofprijzen, getrouwheidskortingen, leveringsweigeringen). ${ }^{21}$ Voor nietgeïntegreerde dominante ondernemingen geldt dan de door het Hof van Justitie in British Airmays (en ook in $M E O)$ gebruikte toets op basis waarvan alleen sprake kan zijn van misbruik indien de schadetheorie aantoont dat de discriminatie 'gelet op alle omstandigheden van het concrete geval, tot doel heeft de mededinging tussen deze handelspartners te verstoren'. ${ }^{22}$ Het is van belang te wijzen op het feit dat de Nederlandse vertaling van de uitspraak, op zijn zachtst gezegd, enigszins onhandig is geformuleerd. Die zou namelijk aanleiding kunnen geven tot het idee dat het Hof van Justitie hier een analogie trekt met een doelbeperking in artikel $101 \mathrm{VWEU}$. Zowel de Engelse als de Franse vertaling van het arrest hanteert echter een andere terminologie op dit punt ('only if the behaviour of the undertaking in a dominant position tends, having regard to the whole of the circumstances of the case, to lead to a distortion of competition'). De relevante toets kan dus beter worden gekwalificeerd als een vorm van discriminatie die de neiging heeft de mededinging te verstoren. ${ }^{23}$ Het Hof van Justitie vereist niet dat bewijs wordt geleverd van een daadwerkelijke en kwantificeerbare verslechtering van de

19. Conclusie A-G Wahl van 20 december 2017 in zaak C-525/16, ECLI:EU:C:2017:1020, MEO. In het volgende nummer van M\&M zullen Wolf Sauter en Eric van Damme uitgebreider stilstaan bij deze uitspraak.

20. Zie ook A-G Wahl hierover in zijn conclusie inzake $M E O$, par. 61 e.v.

21. Conclusie A-G Wahl inzake MEO, par. 76-79.

22. HvJ EG 15 maart 2007, zaak C-95/04 P, British Airways/Commissie, ECLI:EU:C:2007:166, r.o. 144-145; HvJ EU 19 april 2018, zaak C-525/16, MEO, ECLI:EU:C:2018:270, r.o. 25.

23. De rechtbank sluit aan bij deze interpretatie in r.o. 2.10 maar neem ook over dat de gedraging tot doel moet hebben de mededinging te beperken. mededingingspositie van de handelspartners individueel beschouwd. ${ }^{24}$

In de concrete invulling van de door het Hof van Justitie geïntroduceerde formule zou vervolgens gekeken moeten worden naar de vraag hoe significant de voorwaarden waarop is gediscrimineerd nou eigenlijk zijn voor het concurrentieproces, hetgeen uiteraard zeer casuïstisch is zoals de $M E O$-zaak ook illustreert en in feite nagaat of de discriminatie de potentie heeft de mededinging te verstoren. De vaststelling van deze potentie moet vervolgens worden gebaseerd op een analyse van alle relevante omstandigheden van 'het concrete geval' die de slotsom rechtvaardigt dat de discriminatie invloed heeft op de kosten, winsten, of enig ander relevant belang dat de individuele mededingingspositie van een onderneming kan aantasten.

Het is de vraag in hoeverre deze standaard uiteindelijk echt verschilt van een schadetheorie die is gebaseerd op een uitsluitingseffect. Centraal in uitsluiting staat dat de dominante onderneming haar machtspositie versterkt met behulp van andere middelen dan die welke berusten op 'mededinging op basis van verdienste" 25 en dat het gedrag 'naar de aard ervan een beperking van de mededinging tot gevolg zou kunnen hebben', ${ }^{26}$ ongeacht de vraag of het gedrag ook succesvol is. ${ }^{27}$ In Intel verduidelijkte het Hof van Justitie daarbij nog dat voor specifieke situaties waarin de dominante onderneming bewijs aanvoert waaruit volgt dat het prijsgedrag niet in staat zou zijn potentiële uitsluitingseffecten te bewerkstelligen, bijvoorbeeld een mededingingsautoriteit te maken krijgt met een verhoogde bewijslast op basis waarvan een strategie moet worden aangetoond dat het betreffende gedrag was gericht op het uitsluiten van even efficiënte concurrenten. ${ }^{28}$ De basis blijft echter dat een dominante onderneming op basis van haar bijzondere positie in de markt een verantwoordelijkheid heeft de mededinging niet te verslechteren en alleen op merites het concurrentieproces met haar concurrenten mag aangaan.

Het wezenlijke verschil tussen de twee toetsen, tussen uitsluiting en discriminatie, zou daarom als volgt gezien kunnen worden. Bij de discriminatietoets staat de impact van de discriminatie op de individuele onderneming centraal en de vraag in hoeverre die onderneming daarmee een potentieel (maar significant) concurrentienadeel ondervindt met andere handelspartners. Bij de uitsluitingstoets ligt de focus op de gedraging en de afweging in hoeverre die gedraging kan worden gezien als concurrentie op de merites en de potentie heeft tot daadwerkelijke uitsluiting te leiden. De bewijsstandaard zoals geformuleerd in de Europese jurisprudentie vereist dus voor geen van deze schadetheorieën dat bewijs

24. MEO, r.o. 27

25. Bijv. HvJ EU 6 september 2017, zaak C-413/14 P, Intel, ECLI:EU:C: 2017:632, r.o. 134.

26. Bijv. HvJ EU 19 april 2012, zaak C-549/10 P, Tomra Systems e.a./ Commissie, ECLI:EU:C:2012:221, r.o. 68.

27. Bijv. Gerecht 1 juli 2010, zaak T-321/05, AstraZeneca, ECLI:EU:T: 2010:266, r.o. 347 (bevestigd in beroep HvJ EU 6 december 2012, 2012, zaak C-457/10 P, AstraZeneca/Commissie, ECLI:EU:C:2012:770, r.o. 109 en 111).

28. Intel, r.o. 138. 
wordt geleverd van daadwerkelijke effecten. Wat bewezen moet worden (op basis van alle relevante omstandigheden van het geval) in het kader van uitsluiting is de potentie daartoe in het licht van de aard van de betreffende gedraging. Wat bewezen moet worden voor discriminatie is de potentie tot een significante benadeling van de concurrentie van een gediscrimineerde handelspartner op basis van een relevante concurrentieparameter. Hoewel het conceptuele verschil tussen daadwerkelijke en potentiële effecten op die basis wel valt te begrijpen blijft het toch lastig om vervolgens precies in kaart te brengen wat dit nu voor een verschil zou impliceren in het vereiste onderzoek. ${ }^{29}$ Uiteindelijk lopen de twee analyses toch enigszins door elkaar. Ik zal hierna bespreken dat deze verwarring ook zichtbaar is in de uitspraak van de rechtbank.

Gedrag van funda.nl: uitsluiting of discriminatie? Voordat ik bespreek welke toets de rechtbank volgt en hoe die wordt ingevuld is het interessant een klein gedachte-experiment uit te voeren met betrekking tot de vraag wat de juiste toets is om op het gedrag van funda.nl toe te passen. Dit wordt niet expliciet door de rechtbank overwogen, waarschijnlijk omdat het geen onderdeel is van het geschil, maar het feit is natuurlijk dat NVM de controle heeft over funda.nl en dat NVMmakelaars in de stroomafwaartse markt diensten afnemen van funda.nl en tegelijkertijd concurreren met de VBO-makelaars. Hoewel uiteraard noch de NVMmakelaars noch de VBO-makelaars in de stroomafwaartse markt gezien kunnen worden als één onderneming en zij tevens in stevige onderlinge concurrentie staan met elkaar zou toch overwogen kunnen worden dat het feit dat NVM funda.nl controleert een analogie oplevert met de incentives die een verticaal geintegreerde onderneming heeft binnen een dergelijke context. Als collectief hebben de makelaars werkzaam onder de vlag van de NVM op de domnstreammarkt een dominante aanwezigheid (meest recent een marktaandeel van rond de 70 procent ${ }^{30}$ ) en geen belang bij een groter marktaandeel van concurrerende brancheverenigingen. Het gedrag van funda.nl zou daarom ook bezien kunnen worden vanuit het perspectief van potentiële uitsluiting. Daartegenover staat natuurlijk dat de NVM-makelaars uiteraard niet als één onderneming kwalificeren op de domnstreammarkt en ook onderling met elkaar concurreren op die markt. Daarom kan niet zonder meer gesteld worden dat de gedragingen ten opzichte van VBO-makelaars leiden tot uitsluitingseffecten die nadelig zijn voor de con-

29. Vergelijk met de object-effect dichotomie waar een vergelijkbare verwarring blijft bestaan J. Mulder, 'De strekkingsbeperking binnen het Europese mededingingsrecht: het EVA-Hof puzzelt mee', NtEr 2017/5, p. 108-117. In MEO, r.o. 34 stelt het Hof van Justitie vast dat de betreffende bedragen een relatief klein percentage vormden van de totale kosten die MEO droeg in het kader van het aanbieden van haar product en dat de differentiatie in tarieven een beperkte invloed had op de totale winstmarges. Indien de gevolgen van een tariefdifferentiatie voor de kosten die worden gedragen door een marktdeelnemer niet significant zijn, kan worden afgeleid dat deze tariefdifferentiatie geen effect kan hebben op de concurrentiepositie van die marktdeelnemer.

30. Analyse woningmarkt NVM derde kwartaal 2017, toegankelijk op www. nvm.nl (laatst geraadpleegd op 25 juni 2018). currentiestructuur op de markt of ten koste zouden gaan van de consument. Desalniettemin zijn in de rechtspraak van het Hof van Justitie schadetheorieën geaccepteerd op basis van potentiële uitsluiting in situaties waarbij de effecten van een gedraging zich voordoen op een markt waar de dominante onderneming geen emp heeft indien bijzondere omstandigheden dat rechtvaardigen, bijvoorbeeld in het geval van een nauw verband tussen markten. ${ }^{31}$ Omdat NVM funda.nl controleert en haar leden ook profiteren van de gunstige toegang tot funda.nl had wellicht wel beargumenteerd kunnen worden dat sprake is van een bijzondere omstandigheid die toepassing in dit geval zou rechtvaardigen. Daarnaast zou beargumenteerd kunnen worden dat NVM en VBO met elkaar in een concurrentiepositie staan voor wat betreft het aantrekken van makelaars (op zichzelf een economische activiteit: kosten voor het aansluiten van de eerste vestiging bij NVM bedragen $€ 15.000)$. Ik kan me voorstellen dat tegen deze achtergrond het achterstellen van VBO-makelaars op funda.nl een potentieel uitsluitingseffect zou kunnen hebben op een (nog te definiëren) markt voor het aantrekken van individuele makelaars door een branchevereniging.

Deze gedachte-uitstapjes doen verder niet ter zake want de rechtbank beoordeelt de gedragingen onder de noemer van discriminatie. De rechtbank oordeelt dat moet worden onderzocht of de discriminatie het vermogen van de benadeelde handelspartners om een effectieve concurrentiedruk op de bevoordeelde handelspartners uit te oefenen kan aantasten. Het bestaan van een nadeel bij de mededinging zou moeten worden vastgesteld door de daadwerkelijke of potentiële gevolgen van de discriminatie te onderzoeken 'in het licht van alle relevante omstandigheden die verband houden met de betrokken transacties, alsook met de kenmerken van de markt waarop de handelspartners van de onderneming met een machtspositie werkzaam zijn' ${ }^{32}$ In dat onderzoek moet volgens de rechtbank in de eerste plaats aandacht uitgaan naar de realiteit en het relatieve belang van de discriminatie en vervolgens moet ook belang worden gehecht aan het onderzoek van de omvang van de kosten van de door de dominante onderneming geleverde producten/diensten tegenover de totale door de benadeelde handelspartner gedragen kosten. Deze criteria sluiten mooi aan bij de hierboven besproken geldende jurisprudentie mits het aantonen van het relatieve belang van de discriminatie uiteindelijk niet neerkomt op een verplichting dat bewijs wordt geleverd van een daadwerkelijke en kwantificeerbare verslechtering van de mededingingspositie van VBO. ${ }^{33}$ Dat lijkt nu juist wel de wijze te zijn waarop de rechtbank de criteria in casu toepast, overigens grotendeels in lijn met de conclusie van advocaatgeneraal Wahl. Wahl overweegt namelijk dat 'moet worden onderzocht of de litigieuze (...) discriminatie het vermogen van de benadeelde handelspartners om een

31. Bijv. HvJ EG 14 november 1996, zaak C-333/94, Tetra Pak II, ECLI:EU:C:1996:436, r.o. 27

32. Rb. Amsterdam 21 maart 2018, ECLI:NL:RBAMS:2018:1654, r.o. 2.12.

33. HvJ EU 19 april 2018, zaak C-525/16, MEO, ECLI:EU:C:2018:270, r.o. 27. 
effectieve concurrentiedruk op de bevoordeelde handelspartners uit te oefenen, kan aantasten' [cursivering $\mathrm{JM}]{ }^{34}$ De rechtbank oordeelt dat VBO weliswaar te maken heeft gehad met een kostennadeel en 16 procent minder contactaanvragen maar dat dit geen effect heeft gehad op de concurrentiepositie van NVM-makelaars ten opzichte van niet-NVM-makelaars. Hiervoor wordt onder meer nog verwezen naar de marktaandelen van VBO-makelaars, die sinds 2009 niet zijn afgenomen. Daarmee hebben de discriminerende voorwaarden volgens de rechtbank niet de neiging gehad de concurrentieverhoudingen scheef te trekken.

Dit oordeel van de rechtbank is moeilijk te verenigen met de standaard die het Hof van Justitie in $M E O$ heeft benadrukt, namelijk de vraag of de discriminatie een verstoring van de mededinging tussen handelspartners tot gevolg kan hebben. Meer in het bijzonder ten aanzien van de overweging van het Hof van Justitie dat geen bewijs van een daadwerkelijke en kwantificeerbare verslechtering van de mededingingspositie vereist is en dat het voldoende is indien het onderzoek de slotsom rechtvaardigt dat de gedraging een (significante) invloed heeft op de kosten, winsten, of enig ander relevant belang zodat deze gedraging de mededingingspositie kan aantasten. ${ }^{35}$ Uiteindelijk komt dat uiteraard neer op een casuïstische beoordeling van het bewijs maar in de waardering van het bewijs lijkt de rechtbank in deze zaak op zoek te zijn naar een bevestiging dat sprake is van een daadwerkelijke aantasting van het vermogen effectieve concurrentiedruk op de bevoordeelde handelspartners uit te oefenen. Dat is een hogere standaard dan de (significante doch) potentiële nadelige aantasting van de mededingingspositie die vereist wordt door het Hof van Justitie.

Ten aanzien van het door VBO gestelde kostennadeel is dit inderdaad ook in potentie onwaarschijnlijk en wordt niet duidelijk op welke wijze dit een relevante benadeling kan zijn, zeker in het licht van de hoge lidmaatschapskosten van NVM-leden. Met betrekking tot de 16 procent minder contactaanvragen is dit minder vanzelfsprekend. Dit lijkt juist een bevestiging te zijn van het feit dat de plaatsing op funda.nl door verkopers als belangrijke parameter wordt gezien in de keuze van verkopers voor een makelaar. Het feit dat marktaandelen sinds 2009 niet zijn afgenomen is in dat kader niet relevant aangezien de marktaandelen wellicht ook hadden kunnen toenemen in deze periode. Binnen de sleutel die het Hof van Justitie benadrukt in $M E O$ was het niet ondenkbaar dit te beoordelen als een relevant belang dat de mededingingspositie van VBO wel degelijk nadelig heeft kunnen aantasten. Dat roept de vraag op wat nu de relevante counterfactual situatie is die voor dit soort gedragingen moet worden gehanteerd. De nadelige aantasting van de mededingingspositie hoeft slechts in potentie aannemelijk te worden gemaakt maar moet wel relevant/significant zijn en daarmee verhoudingen in de markt negatief beïvloeden. Zoals reeds gezegd: hoewel

34. Conclusie A-G Wahl inzake MEO, par. 99

35. HvJ EU 19 april 2018, zaak C-525/16, MEO, ECLI:EU:C:2018:270, r.o. 27 het conceptuele verschil tussen daadwerkelijke en potentiële effecten wel valt te begrijpen blijft het diffuus wat dit nu uiteindelijk voor een verschil impliceert in het vereiste onderzoek. Op dit punt in de uitspraak is deze ambiguiteit het meest voelbaar. Zou 50 procent minder contactaanvragen wel voldoende zijn geweest? Een vernieuwend idee, gepubliceerd door Ibáñez Colomo en Lamadrid de Pablo in de context van de effect/ object-dichotomie in artikel $101 \mathrm{VWEU}$, is om een alternatief onderscheidend element te gebruiken dat is gebaseerd op de vraag of er een 'plausibele procompetitieve' reden bestaat voor de litigieuze gedraging. ${ }^{36}$ In de toepassing van misbruik van een emp op basis van discriminatie zou dit ook interessant kunnen zijn. Indien op basis van een beoordeling van de juridische en economische context sprake is van een plausibele procompetitieve reden voor de discriminatie dan is er in beginsel geen sprake van een inbreuk. Op deze basis worden de redenen voor het afsluiten van een bepaalde overeenkomst binnen de van toepassing zijnde economische en juridische context doorslaggevend. Bij afwezigheid van een plausibele procompetitieve reden voor discriminatie waarbij tevens een plausibele benadeling van de mededingingspositie is aangetoond zou het vervolgens aan de dominante onderneming zijn om aan te tonen dat de gedraging een netto positieve impact heeft op de mededinging. Het voordeel van deze benadering is dat de eerder geïdentificeerde ambiguiteit verdwijnt aangezien de contextuele functie van een overeenkomst daarmee bepalend wordt. Omdat sprake is van discriminatie en een plausibele benadeling van de mededingingspositie van $\mathrm{VBO}$ op basis van de achterstelling op funda.nl zou binnen deze benadering de discriminatie van VBOmakelaars op funda.nl binnen de relevante juridische en economische context bezien moeten worden. Heeft Funda een procompetitieve reden voor de achterstelling? Op basis van de overeenkomst lijkt de expliciete reden van de achterstelling gelegen in een verbetering van de mededingingspositie van NVM-makelaars ten aanzien van niet-NVM-makelaars. Als zodanig is geen sprake van een economische efficiëntie die normaal gesproken enige differentiatie tussen afnemers zou kunnen rechtvaardigen. Gezien de bijkomende plausibele benadeling van VBO-makelaars zou het vervolgens dus aan funda.nl zijn om te beargumenteren dat het nettoresultaat van de handelswijze alsnog positief is.

Dit geeft aanleiding tot nog één laatste gedachteexperiment. Stel dat funda.nl wel verplicht zou worden de diensten non-discriminatoir aan te bieden. Funda zou kunnen besluiten vervolgens de openstelling van de website voor niet-NVM-makelaars terug te draaien (mits civielrechtelijk mogelijk enz.). ${ }^{37}$ In dat geval wordt

36. P. Ibáñez Colomo en A. Lamadrid de Pablo, 'On the Notion of Restriction of Competition: What We Know and What We Don't Know We in: D. Gerard, M. Merola en B. Meyring (red.), The Notion of Restriction of Competition: Revisiting the Foundations of Antitrust Enforcement in Europe, Bruylant 2017, ook beschikbaar op SSRN: https://ssrn.com/ abstract=2849831.

37. En wellicht zou dat in de eerste plaats vervolgens ook ruimte creëren voor alternatieve huizensiteaanbieders om de positie van funda.nl te 
de Europese rechtspraak relevant met betrekking tot de leveringsweigering van een bestaande afnemer. ${ }^{38} \mathrm{VBO}$ zou een dergelijk besluit kunnen aanvechten door te betogen dat de toegang tot funda.nl kwalificeert als een noodzakelijke input (essential facility) waarvoor toegang noodzakelijk is om überhaupt actief te blijven in de markt omdat het gaat om terbeschikkingstelling van een voor de mededinging onontbeerlijke voorziening. ${ }^{39}$ Het lijkt in eerste instantie onwaarschijnlijk dat deze hogere bewijsstandaard vervolgens kan worden aangetoond gezien de alternatieve platforms die beschikbaar zijn op de markt. Een (wellicht toekomstige) overwinning voor VBO-makelaars in deze zaak zou dus ook een pyrrusoverwinning kunnen zijn. overweegt.

38. HvJ EG 6 maart 1974, gevoegde zaken C-6-73 en C-7-73, Commercial Solvents, ECLI:EU:C:1974:18, r.o. 25.

39. Daarbij zou ook nog relevant kunnen worden geacht dat VBO geen nieuw product aanbiedt in de downstreammarkt - hoewel discussie bestaat ten aanzien van de vraag of dit tweede punt wel een vereiste is in situaties waarbij een bestaande levering wordt stopgezet en geen sprake is van het gebruik van een IE-recht. Zie ook in S. Evrard, 'Essential facilities in the European Union: Bronner and Beyond', Columbia Journal of European Law 2004, nr. 3; J. Turney, 'Defining the Limits of the EU Essential Facilities Doctrine on Intellectual Property Rights: The Primacy of Securing Optimal Innovation', Nw. J. Tech. \& Intell. Prop. 2005, nr. 2. 